\title{
MOTIVATION AND COMMUNICATIVE ATTITUDES AMONG JAPANESE EFL PUPILS
}

\author{
Rie Adachi \\ Aichi University of Technology, Japan \\ rie-adachi@aut.ac.jp
}

Article received: 17 October 2014 Final proof received: 26 June 2015

\begin{abstract}
This paper describes how gender and age affect Japanese pupils' motivation for learning English and their attitudes to communication with people from different cultures. A new foreign language curriculum was introduced to Japanese elementary schools in 2011. Although each school can officially choose any foreign language in its own right, most elementary schools are now conducting English activity. However, as most homeroom teachers lack both experiences and qualifications for teaching English, this activity puts them under pressure. In addition, the number of foreign assistant language teachers (ALTs) is not sufficient in most elementary schools. The writer surveyed fifth and sixth grade pupils' motivation and their communicative attitudes in Japan during 2010, before the new course program, "foreign language activities," began in 2011. The data were collected from three elementary schools in Japan via a questionnaire. The items on the questionnaire are related to motivational attitudes, orientations (reasons for studying a foreign language), communicative attitudes and some other variables relevant to learning foreign languages. The main focus of this study is to examine motivational and attitudinal variables among the pupils with regard to learning English, especially gender and age effects on these variables. The results show that girls generally have higher scores on motivation and communicative attitudes. Most previous studies have also shown that girls generally have a positive attitude toward learning a foreign language. This study argues that the reason behind this positive attitude toward learning English is due to their positive attitude toward communication in general. With regard to the age, there are a few differences between two school grades. As there is only one year difference in age between fifth and sixth grade pupils, the result is to be expected. The study suggests that Japanese elementary schools face a number of difficulties teaching English as it is difficult for teachers to motivate all pupils.
\end{abstract}

Keywords: motivation, communicative attitudes, home room teachers

The need for communication skills in English is more important than ever in Japan as in other countries such as Sweden (Henry and Apelgren, 2008), Hungary (Csizér and Kormos, 2008) and many Asian countries (Butler, 2004, Chen and Cheng, 2010). Since the Ministry of Education, Culture, Sports, Science and Technology (MEXT) revised its curriculum guidelines for Japanese schools in 2008 (MEXT, 2010), an emphasis on communication skills has been reinforced in the teaching of English. High school teachers are required to teach English through the medium of English. "Foreign language activities" have been included in the curriculum for elementary school teachers since April 2011. In December 2013, MEXT announced a plan to introduce English education at elementary schools. It has been said that the decision to introduce English to the elementary school curriculum was due in the first instance to pressure from the industrial world and the public and did not take into account the opinions of education experts (Wada, 2004). As a result, the decision has caused lively debate over its pros and cons (Otsu, 2004).

As Japanese people rarely use English in their daily lives, English is a foreign language rather than a second language for most. Although some young people are familiar with American cultural products including pop music, movies and TV programs, others are more interested in playing games, watching animated films and reading comic books. It is very difficult for Japanese students to motivate themselves to learn English, a situation which Ryan (2009, p.124) described as a "depressing picture." In addition, Japanese people seldom communicate in any foreign languages and have fewer intercultural contacts in their daily lives compared to other countries because the Japanese government has adopted comparatively strict policies on immigration; the number of foreign residents is less than $2 \%$ (Ministry of Justice, 2013). As a result, it is hard for most Japanese people to improve their English communication skills and it is easy for them to lose their motivation to learn English as it is neither a familiar nor a practical language.

For these reasons, it is important to examine students' motivational attitudes and the way in which individual, environmental, cultural and social factors influence their attitudes toward learning English. It is also important to examine the best ways for teachers to foster positive learning attitudes among students.

\section{Background of the study}

Gender-and age-related differences

Until recently, Japanese students normally started to learn English as their first foreign language in junior high school. One of the reasons that English education had not been implemented in public elementary schools before 2011 was the result of previous studies, which suggested 
that teaching English in elementary school had no proven, significant or long-term impact on student abilities and attitudes in later years. For example, a study by Higuchi et al. (2007, p.151), which looked at students from sixth grade in elementary school to second grade in junior high school in three districts, found that the presence of English teaching in elementary schools did not have as much effect on student skills and the affective attitudes of students as expected. Similarly, Takada (2003) and Shirahata (2002) have also argued that there is little difference in attainment levels between students who started learning English in elementary school and those who did not.

However, when it comes to gender, a number of studies in Japan have indicated a common tendency regarding attitudes toward learning English. For example, Carreira $(2006,2011)$ showed that girls had higher scores than boys in terms of their interest in foreign countries and other motivational variables. Mori and Gobel (2006) also found that female students have significantly more positive attitudes to integrativeness, which entails an interest and desire to travel and/or study overseas. In Shizuka's study (2007, p.37), gender was one of the parameter estimates for predicting motivation, namely that motivation is higher in female students than in male students. Research in other countries has shown similar results. For example, Dörnyei and Clément (2001, pp.412-413) indicated that there is a tendency for girls' scores to be significantly higher than those for boys. MacIntyre, Baker, Clément and Donovan (2002) reviewed a number of past studies and noted that girls generally outperformed in second language (L2) learning. However, their study also indicated that the gender effect on motivation is not significant despite the fact that scores on motivational variables were higher for girls than boys. The gender effect was significant only with regards to attitudes toward learning situations (pp.150-154). Dörnyei, Csizér, and Nmeth (2006, pp.5659) also noted that there is a consistent tendency for girls' scores to be significantly higher than scores for boys in motivational dimensions such as integrativeness and instrumentality.

So why do girls generally tend to have more positive attitudes toward foreign languages than boys? Several studies in Japan have shown that girls have a greater interest in other cultures and a more positive attitude toward other community members (Mori and Gobel, 2006, p.205). They have not only better study habits, but also more interest in English, greater English achievement, and more familiarity with English speaking people (Koizumi and Matsuo, 1993, pp.4-10). Nishida (2008, 2011) showed that girls tend to have better motivation, greater interest in other cultures, and greater willingness to communicate (WTC). Carreira (2011, p.88) has also argued that girls are more likely to do their schoolwork voluntarily and to enjoy it in comparison with boys. In studies outside the Japanese context, Dörnyei, Csizér, \& Nmeth (2006), showed that girls have better attitudes toward L2 speakers and communities. They also score higher in terms of cultural interest and intended effort. Baker and MacIntyre (2003, p.89) have also indicated that female non-immersion students showed a significantly more positive orientation toward travel, knowledge, and personal achievement than male students. Henry \& Cliffordson (2013, p.275) stated that gender differences may exist within interdependence and that for women interpersonal relationships will have greater importance. We could therefore speculate that the positive attitude of girls toward other people, other cultures and learning in general may lead to their motivation for learning English. Based on these results, one of the aims of this study is to investigate the kind of attitudes girls display in comparison with boys and to see how these attitudes affect their motivation to learn English in the Japanese context.

With regard to age, researchers have not reached a clear-cut conclusion. Some studies in Japan have shown that motivation toward learning English decreases as students get older (MEXT, 2011, Carreira, 2006). According to MEXT (2011), it also seems that students who do not understand English well tend to lose their interest in learning. Several studies in other countries have suggested that older students have less motivation. For example, Cenoz (2003, pp. 86-87) indicated that the youngest learners (fifth grade) obtained the highest scores both in motivation and attitude toward three foreign languages compared with older participants. Other studies (MacIntyre, Baker, Clément and Donovan, 2002, pp. 552-553; Masgoret, Bernaus, and Gardner, 2001, p. 291) have also suggested that age has a significant effect on motivation, which means that older children tend to have a less positive attitude toward learning English. In this study, since there is only one year's difference between fifth and sixth grade, no significant difference was expected with regard to age, as with previous studies (Adachi, 2009a).

\section{Motivation, intercultural orientations and willingness to} communicate (WTC) with outsiders

With regard to the distinction between integrative and instrumental orientation, Gardner (2001, pp.5-8) argues that integrativeness involves emotional identification with another cultural group. This suggests that identifying with or being open to another community can motivate learning a second language. Instrumental orientation, on the other hand, presents pragmatic reasons for learning the language. Though Gardner (2001, pp. 47) demonstrated that integrativeness is one of the most important factors for motivation as well as attitudes toward the learning situation, he also noted that integrative and instrumental orientation tend to have a significant correlation in several studies. He therefore concluded that neither class of reasons is mutually independent (2001, p.15). In Csizér and Dörnyei (2005, pp.26-27), integrativeness is directly linked to motivated behavior (i.e., language choice). However, their model also showed that instrumentality not only complements integrativeness but also feeds into it. These studies indicate that both integrativeness and instrumental orientation influence attitudes toward learning English as 
a second language and especially learning English as a foreign language (EFL). In addition, Masgoret and Gardner (2003) showed that both integrative and instrumental orientation were correlated with motivation. Bernaus and Gardner (2008, pp.391-392) have also argued that, among the affective variables, the correlation of integrativeness and instrumental orientation with achievement in learning English is significantly high. Both have a significantly high correlation with motivation. Thus, we can conclude that integrative orientation is not the only major factor in learner motivation and that it is not at all significant in the EFL context.

Dörnyei and Csizér (2002, pp.452-454) and Dörnyei (2005) raised an issue about the concept of integrativeness. Henry and Apelgren (2008, p.609) also claimed that integrativeness must be revised conceptually so as to reflect the growing detachment between target languages and the cultural contexts with which they have been traditionally associated. To deal with this issue, Csizér and Dörnyei (2005) and Dörnyei (2005) introduced the theory of the L2 motivational self system, which is made up of three main components; the ideal L2 self, the ought-to L2 self and the L2 learning experience (Dörnyei, 2005, 2009). However, the oughtto L2 self has not been reported significantly in a number of studies (Csizér and Kormos, 2008; Csizér and Lukács, 2010; Kormos and Csizér, 2007). Even with the ideal L2 self and the L2 learning experience, no definite conclusions have been reached. For example, Csizér and Lukács (2010, p.2) indicated that "there remain several issues connected to the model in need of further investigation." The most effective results are drawn from countries where leaning several foreign languages is the norm.

Unlike Sweden, where Henry and Apelgren (2008, p.610) stated that an L2 (English) is an integral part of everyday life, it is difficult for Japanese people to imagine L2 speakers and communities as "the closest parallels". Though Ryan (2009) showed a significant correlation between the ideal L2 self and intended learning efforts within a Japanese educational setting, half of the items measured for the ideal L2 self do not represent his concept of imagining oneself speaking a foreign language, but rather wanting to, dreaming about, or thinking that it is important (p.143). Similarly, Taguchi, Magid, and Papi (2009, pp. 83-6) found that the model of Japanese learners indicated that the impact on the ideal L2 self is much greater from attitudes to L2 culture and community than from instrumental promotion and that the Japanese idealized English self is not strongly linked to a professionally successful self, whereas Chinese and Iranian students had a more salient ideal L2 self. Therefore, it seems that Japanese people have a vague image of the ideal L2 self compared with other learners of English.

In this study, the writer devised two new scales based on the learning context in Japan. The first scale is intercultural orientation. Intercultural orientation is based on the other person who is using English as L2 or
FL, whereas integrative orientation is based on native English speakers. It assumes a favorable attitude toward the outer or expanding circle of communities, which Kachru suggested (as cited in Crystal, 2003, pp. 60-61). Unlike integrative orientation, which is supposed to be a reason to study English in order to integrate with people in the inner circle of community, intercultural orientation will be a reason to learn English in order to communicate with various people in the globalized world, especially for foreign language learners such as Japanese people. Several theoretical reasons underpin the writer's adoption of intercultural orientation.

First, a foreign language learning context is totally different from a second language learning context. As Japanese learners rarely have direct contact with English speaking people and cannot therefore feel the learning effect that arises from such contact, they are less likely identify themselves with English native speakers. For Japanese students, integrating themselves into the American or English community is not an appropriate option.

Secondly, this study assumes that Japanese people will speak English more often with non-native speakers than with native speakers in the future. They will have more opportunities to visit Asian countries than ever before because more and more Japanese companies have expanded their offices and business facilities to other Asian countries. In addition, there are far more people in Japan that speak English as a foreign language than there are native English speakers. Therefore, students will have to interact with various people in English rather than learn English from native English speakers.

Thirdly, it is important for EFL learners to consider English as a language that is not attached to a specific western culture. The dominance of English may have some harmful effects on identity; learners may feel inferior to native English speakers. As Holliday (2005, p. 13) argues, it must be guaranteed that whoever wishes to use English has the right to ownership of it. EFL learners should see English as a communication tool in order to reduce their disadvantages in learning English.

Finally, the scales of integrativeness have not clearly specified the target language speakers for English learners to integrate with and the integrative items in many studies have measured a vague attitude toward the community of native English speakers. However, it is important for EFL learners to understand that integration into the dominant western community is not the only way to acquire English. English is an international language and is used as today's lingua franca; non-native English speakers should also be considered as communication partners.

The second new scale, willingness to communicate (WTC) with outsiders, was also devised to assess pupils' communicative attitudes in various intercultural contexts (Adachi, 2009b, 2011a, 2013). According to MEXT, the ability to communicate is the objective of foreign language activities. However, the communication style varies according to the culture. Besides, communication involves not only verbal but also non-verbal expression. 
MacIntyre, Clément, Dörnyei, and Noels (1998) devised the concept of WTC in an L2, based on the scales of WTC in L1 (McCroskey, 1992), which focused only on verbal communication such as talking or speaking. In this way, the concept of WTC was originally based on the western communication style.

Japanese people, however, tend to regard non-verbal communication, which includes not only physical expression but also the atmosphere or the situation between interlocutors, as rather important. It is said that Japan has a high context culture; the Japanese tend to be more sensitive to non-verbal messages and understand each other with fewer words (Jandt, 2004, p.192). In addition, Japan is an island country with a homogenous population. According to the Ministry of Justice (2013), the ratio of foreign residents to the total population is only $1.6 \%$. Japanese students learn foreign languages to foster positive attitudes toward, and to build a good relationship with people from different cultures. If students do not have positive attitudes toward other people, they will not have any motivation toward learning a foreign language. Japanese students will need to communicate not only with western people, who place a high value on speech communication, but also with the other people in the future. They will need to develop a wider range of viewpoints and a deeper understanding of various cultures and people.

This study has accordingly adopted Adachi's measure of WTC with outsiders. This represents various communicative attitudes "toward people with different ideas" and a tendency to "try to communicate with others" (Adachi, 2012b, p.55), using four items of communicative attitudes (Adachi, 2011a, 2012b, 2013). The measure estimates the degree to which pupils have positive attitudes toward other people who are not in-group members.

\section{METHOD}

\section{Objectives}

The purpose of this study is to investigate pupil motivation and to examine the relationship between motivation and other effect factors during English activities at three elementary Japanese schools and to identify any differences based on gender and age. Note that in these elementary schools English is mostly taught by ALTs. The followings research questions are posed by the study: (1) Are there any differences in pupil motivation and other attitudinal variables between girls and boys? (2) Are there any differences in pupil motivation and other attitudinal variables between fifth and sixth grade?, and (3) How can the motivational scale be explained by other attitudinal variables depending on gender?

\section{Schools and participants}

The survey was conducted in three elementary schools in Japan in March 2010. Table 1 shows the number of students at each school. $\mathrm{K}$ and $\mathrm{N}$ schools are both located in mediumsized cities. School I is located in a heavily populated town with a growing population. All three schools are located in the Aichi prefecture, which is in the central region of Japan.

Before the 2009 academic year, the K, I and N schools implemented English activities. Lessons were conducted in

Table 1. Participants (at the end of the 2009 school year)

\begin{tabular}{crrrr}
\hline $\mathrm{N}$ & Sex (boy/girl) & 5th grade & 6th grade & Total \\
\hline K School & 109 & & & \\
& 95 & 112 & 93 & 205 \\
I School & 77 & & & \\
& 71 & 76 & 72 & 148 \\
N School & 124 & & & \\
& 114 & 123 & 115 & 238 \\
\hline & 590 & 311 & 280 & 591 \\
& 310 & & & \\
boy & 280 & & &
\end{tabular}

the most part by foreign ALTs. The number of classes from first to sixth grade differed depending on each school, ranging from several to a dozen classes. However, the number of classes for fifth and sixth grades was almost 35 in all three schools as shown in Table 2. In preparation for 2011, when foreign language activities were to be formally implemented, homeroom teachers (HRTs) who are in charge of each classroom were required to conduct 35 classes of English activities at many elementary schools. However, the extent to which this was possible depended on the school and the HRT. Since most Japanese elementary school teachers have had neither experience of teaching English, nor the confidence to teach English. Adachi, Sakai, and Aizawa (2014) have showed that some teachers have felt the burden of implementing foreign language activities. Therefore, some of the fifth and sixth grade classes were instructed mainly by ALTs, with other classes being taught by HRTs. The total number of classes went up to almost 35 classes in all schools. The activities mainly comprised games, songs, chants and so on.

\section{Instruments}

The items on the questionnaire were constructed based on several sources (Gardner, 1985; Dörnyei and Clément, 2001; MacIntyre, Baker, Clément, and Donovan, 2002; Yashima, 2002 , etc.). Detailed descriptions of motivational and other variables are described in Adachi (2009a, 2009b, 2010), which adopted the identical questionnaire. Several new scales were developed for this study including intercultural orientation and communicative attitudes with outsiders.

Table 2. The number of classes (at the end of the 2009

\begin{tabular}{|c|c|c|c|c|c|c|}
\hline $\mathrm{N}$ & $1 \mathrm{st}$ & 2nd & $3 \mathrm{rd}$ & 4 th & 5 th & 6 th \\
\hline K School & 11 & 14 & 14 & 14 & 35 & 35 \\
\hline I School & 8 & 8 & 8 & 8 & 35 & 35 \\
\hline N School & 14 & 6 & 6 & $30-35$ & $30-35$ & $30-35$ \\
\hline
\end{tabular}

The number of items in the questionnaire were reduced to reflect age of the pupils and to avoid fatigue. The questionnaires were conducted during class time (Masgoret, 
Bernaus, \& Gardner, 2001; Ryan, 2009). The original questionnaire had a total of 34 items. After checking each item for normal distribution, some items that indicated the floor effect were removed. However, a few attitudinal items which showed a slight ceiling effect were included because they gave a negligible effect. As a result, 28 items were analyzed in this study. They are outlined below (for details, refer to Adachi (2012b)):

1. Motivation (four items). These items were mostly based on the concept of Gardner (1985) and include efforts, desire, and positive attitudes. Enjoying a lesson, learning more English, making an effort to build up vocabulary, and a desire for improvement in English represented positive attitudes.

2. Orientations (nine items). These include possible reasons for studying English (Gardner, 2001) and include intercultural orientation (three items), integrative orientation (three items), and instrumental orientation (three items).

3. People around the learner (three items). These describe how much encouragement pupils get from the people around the learner.

4. Vitality of English (three items). This refers to the extent to which pupils recognize English as a powerful presence in society.

5. Attitudes toward learning (five items). This describes positive attitudes toward language learning.

6. Communicative attitudes (four items). This refers to a number of communicative attitudes toward outsiders, which focused on the extent to which pupils try to communicate with others from different cultures (WTC with outsiders).

\section{Procedures}

The questionnaire was administered in the three schools in March 2010. The HRTs at all three schools conducted the questionnaire during class time. As a result, the collection rate was $100 \%$. Prior to administration, pupils were informed that the answers had nothing to do with their grades. The participants were asked to score each item by choosing from a 6-point Likert scale, most of which ranged from strong agreement $(+6)$ to strong disagreement (1). These data were analyzed using the Statistical Package for the Social Sciences (SPSS) Version 18.

\section{RESULTS AND DISCUSSIONS}

First, the Cronbach alpha index of internal consistency was calculated for each scale based on subsumed items. With regard to orientation, all the 12 orientation items were included in one subscale ${ }^{1}$. As shown in Table 3 , the Cronbach alpha index of internal consistency was acceptable for all subscales.

Next, a multivariate analysis of variance (MANOVA) was performed in order to examine the effects of gender and grade on the six subscales. Table 4 shows the results of the multivariate tests with descriptive statistics for each motivational and attitudinal subscale.
The results showed a significant effect for gender and grade, but no significant effect for gender and grade interaction.

Table 3. Cronbach Alpha for Each Attitudinal Dimension

\begin{tabular}{lcc}
\hline & $\begin{array}{c}\text { Number of } \\
\text { Items }\end{array}$ & $\begin{array}{c}\text { Cronbach } \\
\text { Alpha }\end{array}$ \\
\hline Motivation & 4 & .82 \\
Orientation & 9 & .93 \\
People around the learner & 3 & .86 \\
Vitality of English & 3 & .86 \\
Attitudes toward learning & 5 & .72 \\
Communicative attitudes & 4 & .77 \\
\hline
\end{tabular}

\section{Comparative analysis of motivation and other} attitudinal variables by gender

Significant main effects of gender were found for all six subscales. The main effects of gender impact: motivation $(\mathrm{F}=12.73, \mathrm{p}<.001, \eta 2=.023)$; orientation $(\mathrm{F}=6.75, \mathrm{p}$ $<.001, \eta 2=.01)$; people around the learner $(\mathrm{F}=10.85, \mathrm{p}$ $<.001, \eta 2=.019)$; vitality $(\mathrm{F}=6.22, \mathrm{p}<.001, \eta 2=.01)$; attitudes toward learning $(\mathrm{F}=12.24, \mathrm{p}<.001, \eta 2=.022)$; and communicative attitudes $(\mathrm{F}=13.16, \mathrm{p}<.001, \eta 2$ $=.024)$. As a result, it is clear that girls not only have a more positive attitude than boys with regards to motivation, but they also show a more positive attitude toward learning and communication. In addition, the standard deviation (SD) of all scales showed higher scores in boys than girls, which indicated that there are significant differences among the boys. Therefore, it can be said that girls generally consider learning English to be more important, try harder to learn, and make more of an effort to build good relationships with other people than boys.

In research on student attitudes toward learning English in a Japanese high school, Kobayashi (2002) explained that the superiority of female students in their attitude to English can be attributed to their social status or predictable readiness to look for a new, better life. Based on the results of a study into the co-variation of phonological and sociological variables, Trudgill (1997) has also argued that: "Women are more status-conscious than men, generally speaking, and are therefore more aware of the social significance of linguistic variables." He suggested two reasons for this: the less secure social position of women, and the fact that women are generally rated on signals other than social status, which include speech. However, in the case of the girls in the current study, it is unlikely that they already recognized the potential economic and social effects of English. In fact, they are still in the process of learning the social status of English as the F value for the perceived vitality of English was the lowest among the six subscales.

This study shows that girls not only have higher motivation but also have more positive attitudes toward learning and communication than boys. Their positive attitudes toward communication with others from different cultures may imply that girls have generally 
Table 3. Means and Standard Deviation for Items of Communicative Attitudes and Multivariate Analysis of Variance by Gender and Grade at the End of the 2009 Academic Year

\begin{tabular}{|c|c|c|c|c|c|c|c|}
\hline & \multicolumn{2}{|c|}{ Gender } & \multicolumn{2}{|c|}{ Grade } & \multicolumn{2}{|c|}{ Main Effect } & \multirow[t]{2}{*}{ Interaction } \\
\hline & Boy & Girl & 5 th & 6 th & Gender $F / \eta$ & Grade $F / \eta$ & \\
\hline Motivation & 4.37 & 4.67 & 4.63 & 4.39 & $12.73 * * * .023$ & $8.14^{* * *} .015$ & 3.03 \\
\hline $\mathrm{SD}$ & 1.09 & 0.98 & 0.96 & 1.12 & & & \\
\hline Orientation & 4.37 & 4.60 & 4.47 & 4.49 & $6.75 * * * .012$ & $0.01 \quad .000$ & 0.99 \\
\hline $\mathrm{SD}$ & 1.13 & 0.99 & 1.04 & 1.11 & & & \\
\hline People around learner & 3.53 & 3.89 & 3.79 & 3.61 & $10.85 * * * .019$ & $2.87 \quad .005$ & 0.02 \\
\hline SD & 1.34 & 1.27 & 1.35 & 1.28 & & & \\
\hline Vitality & 4.37 & 4.63 & 4.48 & 4.51 & $6.22 * * * .011$ & $0.06 \quad .000$ & 1.65 \\
\hline $\mathrm{SD}$ & 1.26 & 1.16 & 1.21 & 1.24 & & & \\
\hline Attitudes toward learning & 3.99 & 4.27 & 4.24 & 4.00 & $12.24 * * * .022$ & $9.60 * * .017$ & 0.91 \\
\hline $\mathrm{SD}$ & 1.02 & 0.91 & 0.94 & 1.01 & & & \\
\hline Communicative attitudes & 3.90 & 4.21 & 4.17 & 3.92 & $13.16 * * * .024$ & $8.00 * * .014$ & 2.81 \\
\hline SD & 1.13 & 0.97 & 1.06 & 1.06 & & & \\
\hline
\end{tabular}

$* p<.05 \quad * * p<.01 \quad * * * p<.001$

positive attitudes toward relationships with others. Henry and Cliffordson (2013, p.286) also showed that females are more likely to imagine themselves involved in relationships with others and in situations involving interpersonal interaction than males and these differences appear to have implications for foreign language learning motivation. As they grow older, they will also learn or be told the advantages of learning English from people around them. Adachi (2013) showed that their communicative attitudes were supported by their attitudes toward learning, and that their motivation, attitude toward learning, and communicative attitudes may have a close relationship with each other. As a result, compared to boys, girls tend to consider English more important, study harder, and try harder to build better relationships with others.

Comparative analysis of motivation items and their other attitudinal variables on grades

There were also significant main effects for grade with small effect sizes; the results are shown in Table 4. Grade also had statistically significant main effects on three subscales including motivation $(\mathrm{F}=8.14, \mathrm{p}<.05, \eta 2$ $=.015)$, attitudes toward learning $(\mathrm{F}=9.60, \mathrm{p}<.05, \eta 2$ $=.017)$; and communicative attitudes $(\mathrm{F}=8.00, \mathrm{p}<.05, \eta 2$ $=.014)$. Thus, sixth grade students tend to have less motivation and a less positive attitude toward learning English, even though there is only one year's difference between the two grades. However, unlike in the case of gender, the other three scales showed no decline and sixth graders were more aware of the perceived importance of English (though this was not a significant result). Therefore, although students continue to recognize that learning English is important, their motivation toward learning English tends to decline. The reason for this is not clear but it may be due to "developmentally inappropriate and/or cognitively undemanding instructional practices" (Carreira, 2011, p. 97). This is because the attitudes toward learning of sixth graders, which showed a significant decline, also included attitudes toward general subjects and multiple language learning, not only attitudes related to learning English.

Relationships between motivation and other attitudinal variables by gender

The previous survey showed that girls have significantly higher motivation, better communicative attitudes toward outsiders, better learning attitudes, and so on. It is therefore of considerable importance to explore in more detail how their superiority affects motivation and to clarify the difference of predictors for motivation between girls and boys. Regression analysis was performed in order to predict which attitudinal and motivational scales acted as the best predictors of motivation with regards to gender. As a result, it was found that, for girls, motivation was influenced by attitudes toward learning, people around the learner, orientation, and the perceived vitality of English. The boys' motivation, on the other hand, was affected by attitudes toward learning, people around the learner, and orientation (See Table 5). Therefore, we can say that girls are more affected by a recognition of the importance of English, whereas boys are more conscious of learning. It can be said therefore that girls are more self-disciplined and mature than boys because they are more influenced by the perceived vitality of English; they are less affected by people around the learner. Boys tend to consider the foreign language activity as learning because the score 
for attitudes toward learning was higher for boys than girls as a predictor.

In addition, the writer's previous studies (Adachi, 2011a, 2012a, 2012b, and 2013) have already indicated that attitudes toward learning have a strong effect on motivation. This study has also demonstrated that the score for attitudes toward learning is the most important predictor for both girls and boys. The score for people around the learner also serves as a strong predictor in both genders. Since the participants in this study were elementary school children and people around the learner include not only parents but also teachers and peers, it can be concluded that they tend to be greatly influenced by people in the classroom. This was especially the case with boys because they tended to be more influenced by people around the learner than girls. Butler (2014) found that young learners in her study of Chinese students showed high parent-oriented motivation. It is notable that in the case of Japanese elementary school children, they tend to be influenced not only by their parents but also their teachers and peers. The classroom atmosphere plays a vital role in the development of pupil motivation and communicative attitudes toward other people.

Table 5. Results of the Regression analysis for girls and boys with the motivation scale as the criterion variable

\begin{tabular}{llllll}
\hline & \multicolumn{2}{c}{ Girls } & & \multicolumn{2}{c}{ Boys } \\
\cline { 2 - 3 } \cline { 5 - 6 } & \multicolumn{2}{c}{$\beta$} & & \multicolumn{2}{c}{$\beta$} \\
\hline Attitudes toward learning & .31 & $* * *$ & & .35 & $* * *$ \\
People around learner & .26 & $* * *$ & & .31 & $* * *$ \\
Orientation & .24 & $* * *$ & & .27 & $* * *$ \\
Vitality of English & .14 & $*$ & & & \\
\hline $\mathrm{R}^{2}$ & .65 & $* * *$ & & .67 & $* * *$ \\
\hline
\end{tabular}

\section{CONCLUSION AND IMPLICATIONS}

This study shows that girls generally have high scores on motivational items and a number of other attitudes. Although there is not as much difference due to age in comparison with gender because of the one year's difference between fifth and sixth graders, significant differences are nevertheless found for motivation, attitudes toward learning and communicative attitudes. Teachers will have more difficulties teaching foreign languages if the number of English classes increases. When schools implement foreign language activities, it is very important that they think about ways to motivate boys, especially as they get older. The higher scores in the $\mathrm{SD}$ of all scales for boys showed that there are large variations in their attitudes to foreign language activities. This means that some boys will gradually become more motivated toward learning English, whereas as other boys will gradually lose interest. On the other hand, the result of the study shows that girls generally consider learning a foreign language more important, try harder to learn, and make more effort to build good relationships with other people. This study reveals that girls tend to consider relationships with others as important.

Concerning the relationship between motivation and other attitudinal variables, boys are more influenced by people around the learner than girls. This implies that they are immature compared with girls and susceptible to the opinions of other classmates. Besides, as boys are not influenced by the perceived vitality of English, they tend not to be able to recognize the importance of learning English. Therefore, in order to motivate boys, teachers will need to explain why learning English is important and offer reasons why pupils should learn English. They should try to create a positive classroom atmosphere for English lessons. In addition, as girls tend to have higher motivation and better communicative attitudes, teachers need to maintain their motivation and positive communicative attitudes by devising a better way to implement foreign language activities and teach English.

However, even in today's globalized society, the Japanese language is not inadequate for science, technology, and business. With its high level of wages, Japan cannot compete directly with low-wage countries such as India and the Philippines, and as a result, the benefits of global English are largely limited to a relatively small elite in Japan (Yanagami \& Tollefson, 2011). In addition, MEXT (2014) stated that many problems remain to be resolved before English teaching can be introduced in elementary schools. These problems include ensuring an adequate number of English teachers, teacher training, providing teachers with enough time for training, preparing a suitable environment for teaching at elementary schools (including tools for information communication technology (ICT)), designing learning contents (which should focus on communication abilities and communicative attitudes), examining how to evaluate pupils' communicative abilities and so on. If English teaching is added to the curriculum for Japanese elementary schools without adequate preparation, motivating pupils will be more difficult.

It may be more difficult for teachers to convince students of the need to learn English than to actually teach them when pupils (especially boys) tend to lose their motivation. Orientation in this study, which represents the reasons for studying English, included all three kinds of orientation, intercultural orientation, integrative orientation, and instrumental orientation. The result showed that pupils may not realize the definite reason why they need to study English and they do not have a clear image of the ideal L2 self. That is one of the reasons why it is very difficult for teachers to motivate every student in Japan. Teachers or educators will have to take on more responsibility for motivating pupils as the number of English classes increases. Further investigation into both age- and gender-related differences will be necessary in order to verify the results of this study, and future research should continue to explore the question of pupil motivation and communicative attitudes as schools and social situations change. 


\section{Acknowledgement}

This study was supported by Grant-in-Aid for Scientific Research (KAKENHI) (C), (No.23520768). She would like to thank the principal, HRTs and pupils for their kind cooperation to take time for this research.

\section{REFERENCES}

Adachi, R. (2009a). Age-related differences regarding motivation and orientation of young Japanese EFL learners. Language Education and Technology Journal of Central Japan, 20, pp. 2134.

Adachi, R. (2009b). Motivation of young Japanese EFL learners and effect factors. JASTEC Journal, 28, pp. 43-64.

Adachi, R. (2010). A structural equation model of motivation and attitudes of young Japanese foreign language learners. Language Education and Technology Journal of Central Japan, 47, pp. 205-226.

Adachi, R. (2011a). The effect of increased English activities on sociocultural attitudes and intercultural communicative attitudes of young Japanese learners. JACET Journal, 52, pp. 1-18.

Adachi, R. (2012a). Japanese elementary students' motivational and communicative attitudes in accordance with the increase of foreign language activities. Journal of the Chubu English Language Education Society, 41, pp. 125-130.

Adachi, R. (2012b). A motivational model in Japanese elementary students' foreign language activities. Language Education and Technology, 49, pp. 4764.

Adachi, R. (2013). Pupils' changes in communicative attitudes toward English activities; A case study at a Japanese elementary school. Annual Review of English Language Education in Japan, 24, pp. 221-233.

Adachi, R., Sakai, S., \& Aizawa, M. (2014). A study of Japanese elementary school teachers' perceptions of foreign language activities. Language Teacher Education, 1, pp. 50-69., (JACETSIG-ELE Journal).Retrieved Fenruary 3, 2013 from: http://www.waseda.jp/assocjacetenedu/VOL1NO2.pdf

Baker, S. C. \& MacIntyre, P. D. (2003). The role of gender and immersion in communication and second language orientations. Language Learning, 53, pp. 65-96.

Bernaus, M. \& Gardner, R.C. (2008). Teacher motivation strategies, student perceptions, student motivation, and English achievement. The Modern Language Journal, 92, pp. 387-401.

Butler, Y. G. (2004). What level of English proficiency do elementary school teachers need to attain to teach EFL? Case studies from Korea, Taiwan, and Japan. TESOL Quarterly, 38, pp. 245-278.

Butler, Y. G. (2014). Parental factors and early English education as a foreign language: A case study in Mainland China. Research Papers in Education,
29, pp. 410-437.

Carreira, M.J. (2006). Developmental trend and gender differences in affective variables influencing English as a foreign language learning among Japanese elementary school pupils. JASTEC Journal, 25, pp. 57-74.

Carreira, M.J.(2011). Relationship between motivation for learning EFL and intrinsic motivation for learning in general among Japanese elementary school students. System, 39, pp. 90-102.

Cenoz, J. (2003). The influence of age on the acquisition of English: General proficiency, attitudes and code-mixing. In Garcia Mayo, M. P., \& Garcia Lecumberri, M. L. (Eds.), Age and the acquisition of English as a foreign language (pp.77-93). Clevedon, UK: Multilingual Matters Ltd.

Chen, C. W., \& Cheng, Y. (2010). A case study on foreign English teachers' challenges in Taiwanese elementary schools. System, 38, pp. 41-49.

Crystal, D.(2003). English as a global language (2nd edition). Cambridge: Cambridge University Press.

Csizér K., \& Dörnyei, Z. (2005). The internal structure of language learning motivation and its relationship with language choice and learning effort. The Modern Language Journal, 89. pp.1933.

Csizér, K. \& Kormos, J. (2008). The relationship of intercultural contact and language learning motivation among Hungarian students of English and German. Multilingual and Multicultural Development, 29 , pp. 30-45.

Csizér, K. \& Lukács, G. (2010). The comparative analysis of motivation, attitudes and selves: The case of English and German in Hungary. System, 38 , pp. 1-13

Dörnyei, Z. (2005). Motivation and "Self-Motivation". In Z. Dörnyei (Ed.). The psychology of the language attitudes and learner: Individual differences in second language acquisition. (pp.65-119). NJ: Lawrence Erlbaum.

Dörnyei, Z. (2009). The L2 Motivational self system. In Z. Dörnyei \& E. Ushioda (Eds.), Motivation, language identity and L2 self. (pp.9-42). Clevedon, UK: Multilingual Matters.

Dörnyei, Z. \& Clément, R. (2001). Motivational characteristics of learning different target languages: Results of a nationwide survey. In Z . Dörnyei \& R. Schmidt (Eds.), Motivation and second language acquisition (pp.399-432). Honolulu: University of Hawai'i press.

Dörnyei, Z., \& Csizér K. (2002). Some dynamics of language attitudes and motivation: Results of a longitudinal nationwide survey. Applied Linguistics, 23, pp. 421-462.

Dörnyei, Z., Csizér, K., \& Nmeth, N. (2006). Modifying factors in language attitudes and Motivation: Gender, geographical location and school instruction. Motivation, language attitudes and globalisation: A Hungarian perspective. 
(pp.55-72). Clevedon, UK: Multilingual Matters LTD.

Gardner, R.C. (1985). Social psychology and second language learning: The role of attitudes and motivation. London: Edward Arnold.

Gardner, R.C. (2001). Integrative motivation and second language acquisition. In Z. Dörnyei \& R. Schmidt (Eds.), Motivation and second language acquisition (pp.1-21). Honolulu: University of Hawai'i Press.

Henry, A. \& Apelgren, B.T. (2008). Young learners and multilingualism: A study of learner attitudes before and after the introduction of a second foreign language to the curriculum. System, 36, pp. 607-623.

Henry, A. \& Cliffordson, C. (2013). Motivation, gender, and possible selves. Language Learning, 63(2), pp. 271-295.

Higuchi, T., Omura, Y. Tanabe, Y., Kunikata, F., Kagata, T., Izumi, E. \& et al. (2007). Syogakko Ekigo Gakusyu Keikensya no Tsuiseki Chosa to Syo Chu Gakko Eigo Kyoiku heno Shisa [A follow-up survey of ELES experienced students and its implication on the future English instruction at elementary school and junior high school]. Kinki University Language Education Bulletin, 7(2), pp. 123-180.

Holliday, A. (2005). The struggle for new relationship. In A. Holliday (Ed.). The struggle to teach English as an international language (pp.1-16). Oxford: Oxford University Press.

Jandt, F. E. (2004). An introduction to intercultural communication: Identities in a global community (4th edition). CA: Sage publications.

Kobayashi, Y. (2002). The role of gender in foreign language learning attitudes: Japanese female students' attitudes towards English learning. Gender and Education, 14, pp. 181197.

Koizumi, R., \& Matsuo, K. (1993). A longitudinal study of attitudes and motivation in learning English among Japanese seventh-grade students. Japanese Psychological

Research, 35(1), pp. 1-11.

Kormos, J. \& Csizér, K. (2007). An interview study of inter-cultural contact and its role in language learning in a foreign language environment. System, 35, pp. 241-258.

MacIntyre, P. D., Clément, R., Dörnyei, Z., \& Noels, K. (1998). Conceptualizing willingness to communicate in a L2: A situational model of L2 confidence and affiliation. The Modern Language Journal, 82, pp. 545-562.

MacIntyre, P. D., Baker, S. C., Clément, R., \& Donovan, L. A. (2002). Sex and age effects on willingness to communicate, anxiety, perceived competence, and L2 motivation among junior high school French immersion students. Language Learning, 52, pp. 537-564.

Masgoret, A.-M., Bernaus, M., \& Gardner, R.C. (2001). Examining the role of attitudes and motivation outside of the formal classroom: A test of the MINI-AMTB for children. In Z. Dörnyei \& R. Schmidt (Eds.), Motivation and second language acquisition (pp.281-295). Honolulu: University of Hawai'i press.

Masgoret, A.-M., \& Gardner, R. C. (2003). Attitudes, motivation in second language learning: A metaanalysis of studies conducted by Gardner and associates. Language Learning, 53, pp. 123-163.

McCroskey, J. C. (1992). Readability and validity of the willingness to communicate scale. Communication Quarterly, 40(1), pp. 16-25.

Ministry of Education, Culture, Sports, Science \& Technology (MEXT). (2010). Curriculum for Elementary Schools. Chapter 4 Foreign Language Activities. Retrieved January 10, 2013 from: http:/www.mext.go.jp/component/a_menu/educat ion/micro_detail/_icsFiles/afieldfile/2010/10/20/ $1261037 \overline{1} 2 . p d f$

Ministry of Education, Culture, Sports, Science \& Technology (MEXT). (2011). Kokusai kyotsugo to shiteno eigoryoku kojo notameno itsutsu no teigen to gutaiteki shisaku [Five proposals and concrete measures for improving ability of English as the international lingua franca]. Retrieved January 10, 2015 from: http://www.mext.go.jp/component/b_menu/shingi/ toushin/_ icsFiles/afieldfile/2011/07/13/1308401 3.pdf

Ministry of Education, Culture, Sports, Science \& Technology in Japan (MEXT). (2014). Kongo no eigokyouiku no kaizen jujitsu hosak nitsuite hokoku [A report on improvement and enhancement of future English education]. Retrieved January 10, 2013 from http://www.mext.go.jp/b_menu/shingi/chousa/shot ou/102/shiryo/attach/1352317.htmHE

Ministry of Justice (2013). Heisei 24 nendomatsu ni okeru zairyu gaikokujin ni tsuite [The foreign residence in Japan at the end of 2012]. Retrieved January 10, 2013 from:

http://www.moj.go.jp/nyuukokukanri/kouhou/nyu ukokukanri04_00030.html

Mori, S. \& Gobel, P. (2006). Motivation and gender in the Japanese EFL classroom, System 34, pp. 194210.

Nishida, R. (2008). An Investigation of Japanese public elementary school students' perception and anxiety in English learning: A pilot study comparing 1 st to 6 th graders, LET, 45, pp.113131.

Nishida, R. (2011). Elementary school pupils' motivation and affective variables in foreign language activities as related to annual hours of English instruction, LET Kansai Chapter 13, pp. 1-15.

Otsu, Y. (2004). Koritsu syogakko deno eigo kyoiku. [English education at public elementary schools] Y. Otsu (Ed.), Syogakko deno eigo kyoiku ha hitsuyoka [Is English education necessary at 
elementary schools?]. Keio University Press.

Ryan, S. (2009). Self and identity in L2 motivation in Japan: The ideal L2 self and Japanese learners of English. In Z. Dörnyei \& E. Uhioda (Eds.), Motivation, language identity and the L2 Self (pp.120-143). Clevedon, UK: Multilingual Matters.

Shirahata, T. (2002). An investigation into English abilities of the students who were exposed to English at a model school. The Bulletin of the Faculty of Education, Shizuoka University, Educational Research Series, 33, pp. 195-215.

Shizuka, T. (2007). Effects of learning English in elementary school days on the proficiency of, and the attitude towards, the language in high school years (II). JACET Journal, 31, pp. 31-45.

Taguchi, T., Magid, M. \& Papi, M. (2009). The L2 motivational self system among Japanese, Chinese, \& Iranian learners of English: A comparative study. In Z. Dörnyei \& E. Uhioda (Eds.), Motivation, language identity and the L2 Self (pp.120-143). Clevedon, UK: Multilingual Matters.
Takada, T. (2003). Learner characteristics of early starters and late starters of English language learning: anxiety, motivation, and aptitude. JALT Journal, 28, pp. 135-158.

Trudgill, P. (1997). The social differentiation of English in Norwich. In N. Coupland \& A. Jaworski (Eds.), Sociolinguistics (pp.179-184). London: Palgrave Macmillan.

Wada, M. (2004). Syogakko Eigo Kyoiku, Gengo Seisaku, Taisyu.[English education at elementary schools, language policy, and people.] Y. Otsu (Ed.), Syogakko deno eigo kyoiku ha hitsuyoka[Is English education necessary at elementary schools?]. Keio University Press.

Yanagami, M. \& Tollefson, J.W. (2011). Elite discourses of globalization in Japan: The role of English. P. Seargeant (Ed.), English in Japan in the Era of Globalization, (pp.15-37). London: Palgrave Macmillan.

Yashima, T. (2002). Willingness to communicate in a second language: Japanese EFL context. The Modern Language Journal, 86, pp. 54-66. 